\title{
The Supportive Role of Dietary Antioxidants in Antioxidant Defence System
}

\author{
Abiodun Olusoji Owoade* Adewale Adetutu Olubukola Sinbad Olorunnisola \\ Department of Biochemistry, Ladoke Akintola University of Technology, Ogbomosho, Nigeria
}

\begin{abstract}
Reactive oxygen and nitrogen species are generated both endogenously and in response to external factors, such as diet and lifestyle, and play a major role in the aetiology of several degenerative diseases. The effect of reactive oxygen species (ROS) and reactive nitrogen species (RNS) is balanced by the antioxidant action of enzymatic antioxidants such as superoxide dismutase, glutathione peroxidase, catalase, antioxidant compounds such as, thioredoxin, lipoic acid and dietary antioxidant such as Vitamin C, Vitamin E, carotenoids, flavonoids. Antioxidant defences are extremely important as they represent the direct removal of free radicals, thus providing protection for biological sites. However, as this protection may not be sufficient to entirely prevent the damage by ROS/RNS, consumption of food rich in dietary antioxidants which offers supportive role in antioxidant defence system in removing excessive ROS/RNS become even more important in protecting cell biomolecules against oxidative damage.
\end{abstract}

Keywords: Reactive oxygen species, Free radicals, Antioxidants, Cell biomolecules, Oxidative damage.

DOI: $10.7176 /$ ALST/73-06

Publication date: April $30^{\text {th }} 2019$

\section{Diets and Diseases}

Diets appear to play an important role in human health and in the development of certain diseases such as cancer and cardiovascular disease (Rahman, 2001; Liu, 2004). These two diseases are the top causes of death in the United States and in most industrialized countries (Liu, 2004). Interestingly, several epidemiological studies have consistently shown that diets rich in fruit and vegetables promote health, and attenuate, or delay the onset of chronic diseases (Fraga, 2007). Therefore, changes in dietary behaviour, such as increasing consumption of fruits, vegetables and whole grains is a practical strategy for significantly reducing the incidence of chronic diseases (Liu, 2004). Plant based foods contain significant amounts of bioactive phytochemicals (e.g Polyphenols) which may provide desirable health benefits beyond basic nutrition to reduce the risk of chronic diseases (Liu, 2004). There is more and more convincing evidence to suggest that the health benefits of phytochemicals in fruits and vegetables may be due to their antioxidant action, because oxidative stress induced by free radicals is involved in the aetiology of wide range of chronic diseases (Sayre et al., 2001; Jenner, 2003; Dalle-Donne et al., 2006).

\section{Reactive Oxygen and Nitrogen Species}

Reactive oxygen species (ROS) and Reactive nitrogen species (RNS) are generated in vivo from incomplete reaction of oxygen during aerobic metabolism, stimulated host phagocytes, or from exposure to environmental agents such as radiation and redox cycling agents (Park et al., 2003). ROS include free radicals (which are defined as molecules or molecular fragments containing one or more unpaired electrons) such as superoxide $\left(\mathrm{O}_{2}{ }^{-}\right)$, hydroxyl $\left(\mathrm{OH}^{*}\right)$, peroxyl (ROO'), hydroperoxyl (HROO') as well as non-radical species such as hydrogen peroxide $\left(\mathrm{H}_{2} \mathrm{O}_{2}\right)$ and hypochlorous acid ( $\left.\mathrm{HOCl}\right)$ (Evans et al., 2002; Turko and Murad, 2002). RNS include free radicals like nitric oxide $\left(\mathrm{NO}^{*}\right)$ and nitrogen dioxide $\left(\mathrm{NO}_{2}{ }_{2}\right)$, as well as nonradicals such as peroxynitrite $\left(\mathrm{ONOO}^{-}\right)$, nitrous oxide $\left(\mathrm{HNO}_{2}\right)$ and alkyl peroxynitrates (RONOO) (Evans et al., 2002; Turko and Murad, 2002). Reactive oxygen and nitrogen species play a dual role in biological systems, since they can be either harmful or beneficial to living systems (Valko et al., 2006). Beneficial effects of ROS which occur at low/moderate concentrations include (a) physiological roles in cellular responses to stress, as for example in defence against infectious agents and (b) the induction of a mitogenic response (Valko et al., 2006). The harmful effect of ROS includes widespread damage to macromolecules leading to lipid peroxidation, protein oxidation and DNA base modification and strand breaks (Poli et al., 2004; Stocker and Keaney, 2004). This damage effect is termed oxidative and nitrosative stress (Kovacic and Jacintho, 2001; Ridnour et al., 2005). Oxidative and nitrosative stress is defined in general as excess formation and/or insufficient removal of highly reactive molecules such as reactive oxygen species (ROS) and reactive nitrogen species (RNS) (Turko et al., 2001; Maritim et al., 2003). This occurs in biological systems when there is an overproduction of ROS/RNS on one side and a deficiency of enzymatic and non-enzymatic antioxidants on the other (Valko et al., 2007). The excess ROS are harmful because they can damage cellular lipids, proteins, and DNA which are the most important biomolecules in the human body (Orhan et al., 2006). Because of this, oxidative stress has been implicated in the development of many ageing-related diseases, like cancer, cataract and heart diseases (Dalle-Donne et al., 2006). 


\section{Antioxidants}

The effect of reactive oxygen and nitrogen species is balanced by the antioxidant action of non-enzymatic antioxidants, as well as by antioxidant enzymes. Antioxidant defences helps in direct removal of free radicals (prooxidants), thus providing maximal protection for biological sites. Enzymatic antioxidant defences include superoxide dismutase (SOD), glutathione peroxidase (GPx), catalase (CAT). Non-enzymatic antioxidants are represented by ascorbic acid (Vitamin C), $\alpha$-tocopherol (Vitamin E), glutathione (GSH), carotenoids, flavonoids, and other antioxidants.

\section{Enzymatic Antioxidants}

\subsection{Superoxide Dismutase (SOD)}

Superoxide dismutase (EC 1.15.1.1) is the antioxidant enzyme that catalyzes the dismutation of $\mathrm{O}_{2}{ }^{-{ }^{-}}$to $\mathrm{O}_{2}$ and to the less-reactive species $\mathrm{H}_{2} \mathrm{O}_{2}$. In humans there are three forms of SOD: cytosolic $\mathrm{Cu}, \mathrm{Zn}-\mathrm{SOD}$, mitochondrial Mn-SOD, and extracellular SOD (EC-SOD) (Landis and Tower, 2005). Cu, Zn-SOD is an enzyme with a molecular weight of about $32 \mathrm{kDa}$ and is composed of two identical subunits (homodimer) (Mates et al., 1999; Valko et al., 2006). $\mathrm{Cu}, \mathrm{Zn}-\mathrm{SOD}$ specifically catalyzes the dismutation of the superoxide anion to oxygen and water. Each subunit contains as the active site, a dinuclear metal cluster constituted by copper and zinc ions. Mitochondrial Mn-SOD is a homotetramer (96 kDa) containing one manganese atom per subunit (Mates et al., 1999; Valko et al., 2006). This enzyme cycles from Mn (III) to Mn (II) and back to Mn (III) during the two step dismutation of superoxide. Extracellular superoxide dismutase (EC-SOD) is a secretory, tetrameric, copper and zinc containing glycoprotein, with a high affinity for certain glycosaminoglycans such as heparin and heparin sulphate (Mates et al., 1999; Valko et al., 2006). Its regulation in mammalian tissues occurs primarily in a manner coordinated by cytokines, rather than as a response of individual cells to oxidants. A completely distinct SOD class that contains Ni (Ni-SOD) was recently discovered in Streptomyces and cyanobacteria. Ni-SOD is a small 117 amino acids protein with no sequence homology to other SODs (Barondeau et al., 2004).

\subsection{Catalase}

Catalase (EC 1.11.1.6) is an enzyme present in the cells of plants, animals and aerobic (oxygen requiring) bacteria (Mates et al., 1999; Valko et al., 2006). Catalase is located in a cell organelle called the peroxisome. The enzyme very efficiently promotes the conversion of hydrogen peroxide to water and molecular oxygen. Catalase has one of the highest turnover rates for all enzymes: one molecule of catalase can convert $\sim 6$ million molecules of hydrogen peroxide to water and oxygen each minute:

$$
2 \mathrm{H}_{2} \mathrm{O}_{2} \longrightarrow 2 \mathrm{H}_{2} \mathrm{O}+\mathrm{O}_{2}
$$

The significantly decreased capacity of a variety of tumours for detoxifying hydrogen peroxide is linked to a decreased level of catalase (Valko et al., 2006).

\subsection{Glutathione Peroxidase}

There are two forms of the enzyme glutathione peroxidase, one of which is selenium-independent (glutathioneS-transferase, GST, EC 2.5.1.18) while the other is selenium-dependent (GPx, EC 1.11.1.19) (Mates et al., 1999). All GPx enzymes are known to add two electrons to reduce peroxides by forming selenoles (Se-OH). The antioxidant properties of these selenoenzymes allow them to eliminate peroxides as potential substrates for the Fenton reaction. GPx acts in conjunction with the tripeptide glutathione (GSH), which is present in cells in high (micromolar) concentrations. The substrate for the catalytic reaction of GPx is $\mathrm{H}_{2} \mathrm{O}_{2}$, or organic peroxide ROOH. GPx decomposes peroxides to water (or alcohol) while simultaneously oxidizing GSH:

$$
\begin{array}{rlr}
2 \mathrm{GSH}+\mathrm{H}_{2} \mathrm{O}_{2} & \mathrm{GPx} & \mathrm{GSSG}+2 \mathrm{H}_{2} \mathrm{O} \\
\cline { 2 - 3 }+\mathrm{ROOH} & \mathrm{GPx} & \mathrm{GSSG}+\mathrm{ROH}+\mathrm{H}_{2} \mathrm{O}
\end{array}
$$

Significantly, GPx competes with catalase for $\mathrm{H}_{2} \mathrm{O}_{2}$ as a substrate and is the major source of protection against low levels of oxidative stress.

\section{Non-Enzymatic Antioxidants}

\subsection{Glutathione}

Glutathione (GSH) is a multifunctional intracellular non-enzymatic antioxidant. Glutathione is highly abundant in the cytosol $(1-11 \mathrm{mM})$, nuclei $(3-15 \mathrm{mM})$, and mitochondria $(5-11 \mathrm{mM})$ and is the major soluble antioxidant in these cell compartments (Masella et al., 2005). The reduced form of glutathione is GSH, glutathione, and the oxidised form is GSSG, glutathione disulphide. GSH in the nucleus maintains the redox state of critical protein sulphydryls that are necessary for DNA repair and expression. An oxidative environment leads to rapid modification of protein sulphydryls (protein-SH) to sulphenic acids (protein-SOH) and thiyl radicals (protein- $\mathrm{S}^{*}$ ) 
(Valko et al., 2006). These partially oxidised products are restored back to protein sulphydryls (protein-SH) by reaction with GSH. Glutathione react with the radical $\mathrm{R}^{\bullet}$ to form thiyl radicals

$$
\mathrm{GSH}+\mathrm{R}^{\bullet} \rightarrow \mathrm{GS}^{\bullet}+\mathrm{RH}
$$

Thiyl radicals generated may dimerise to form the oxidised glutathione

$$
\mathrm{GS}^{\bullet}+\mathrm{GS}^{\bullet} \rightarrow \mathrm{GSSG}
$$

Oxidised glutathione GSSG is accumulated inside the cells and the ratio of GSH/GSSG is a good measure of oxidative stress of an organism (Nogueira, 2004). Too high a concentration of oxidised glutathione GSSG may damage many enzymes oxidatively. The main protective roles of glutathione against oxidative stress are (i) glutathione is a cofactor of several detoxifying enzymes against oxidative stress, (ii) GSH participates in amino acid transport through the plasma membrane; (iii) GSH scavenges hydroxyl radical and singlet oxygen directly, detoxifying hydrogen peroxide and lipid peroxides by the catalytic action of glutathione peroxidase; (iv) glutathione is able to regenerate the most important antioxidants, vitamins $\mathrm{C}$ and $\mathrm{E}$ back to their active forms (Masella et al., 2005). The capacity of glutathione to regenerate the most important antioxidants is linked with the redox state of the glutathione disulphide-glutathione couple (GSSG/2GSH) (Pastore, 2003).

\subsection{Vitamin E}

The major antioxidant function of vitamin $\mathrm{E}$ is inhibition of lipid peroxidation. Lipid peroxyl radicals are scavenged by vitamin E to yield lipid hydroperoxide and tocopheroxyl radical which is less reactive towards neighbouring PUFA and acts as a chain - breaking antioxidant (Aviram et al., 2005). In addition, vitamin E has been shown to be able to quench singlet oxygen and interact with peroxynitrite. Vitamin $\mathrm{E}$ has been shown to reduced AAPH induced oxidative stress in rat erythrocytes (Shiva et al., 2007) and extend the average and maximum life span of will-type flies under oxidative stress condition (Bahadorani et al., 2008). In addition, dietary supplementation with Vitamin $\mathrm{E}$ has been shown to decrease the risk of prostate cancer in smokers (Kirsh, 2006).

\subsection{Vitamin $C$}

Vitamin $\mathrm{C}$ is oxidized to dehydro - ascorbate when it interacts with ROS, which is subsequently recycled back to ascorbic acid by the enzyme dehydro - ascorbate reductase. Vitamin $\mathrm{C}$ has been shown to scavenge different ROS such as superoxide radical anion, $\mathrm{H}_{2} \mathrm{O}_{2}$, the hydroxyl radical and singlet oxygen (Tariq, 2007). It is also effective against reactive nitrogen oxide species (RNS), preventing the nitrosation of target molecules. Vitamin $\mathrm{C}$ has been shown to reduce AAPH induced oxidative stress in rat erythrocytes (Shiva et al., 2007) supplementation of rat diet with Vitamin $\mathrm{C}$ protect rats against liver damage induced with gamma radiation (Adaramoye et al., 2008) and extend the life span of wild-life flies under normoxia condition (Bahadorani et al., 2008). However, vitamin $\mathrm{C}$ can also act as a prooxidant in vivo in the presence of free metal ions $\left(\mathrm{Fe}^{2+}\right.$ and $\left.\mathrm{Cu}^{2+}\right)$ (Bahadorani, 2008)

\subsection{Carotenoids}

Carotenoids are natural colourants with pronounced antioxidant activity. They have been shown to be an effective scavenger of singlet oxygen $\left({ }^{1} \mathrm{O}_{2}\right)$ peroxyl, hydroxyl and superoxide radicals (Trevithick-Sutton et al., 2006; Sachindra et al., 2007). Caratenoids play important functions in photosynthesis and photoprotection in plant tissues, this is due to their ability to quench and inactivate reactive oxygen species such as singlet oxygen $\left({ }^{1} \mathrm{O}_{2}\right)$ formed from exposure of light and air (Lui, 2004). Dietary supplementation with $\beta$-carotene, lycopene and soy isoflavones have been shown to lower the risk of prostate cancer (Kirsh et al., 2006; Vaishampayan et al., 2007) and intake of both $\beta$-carotene/lycopene either in food or by supplementation have been shown to be inversely related to the risk of coronary artery disease (Ahuja et al., 2006; Bose and Agrawal, 2007)

\subsection{Phenolics}

Phenolic are the products of secondary metabolism in plants, providing essential functions in the reproduction and growth of plants. They are categorized as phenolic acid, flavonoids, stilbenes, coumarins and tannins. In additions to their roles in plants, phenolic compounds in our diet may provide health benefits associated with reduced risk of chronic diseases. Phenolics in our diet are made up of two thirds flavonoids and one third phenolic acids (Lui, 2004).

5.5.1. Phenolic Acids

Phenolic acids can be subdivided into two major groups, hydroxybenzoic acids and hydroxycinnamic acids. Hydroxybenzoic acid derivatives include $p$-hydroxybenzoic, protocatechuic, vannilic, syringic, and gallic acids, while Hydroxycinnamic acid derivatives include $p$-coumaric, caffeic, ferulic, and sinapic acids. Chlorogenic acids and curcumin are the major derivatives of hydroxycinnamic acids present in plants. Chlorogenic acids are the ester of caffeic acids while curcumin is made of two ferulic acids. Phenolic acids are commonly present in the bound form, linked to cell-wall structural components such as cellulose and lignin. Food processing, such as 
thermal processing, pasteurization, fermentation, and freezing, contributes to the release of these phenolic acids (Dewanto, 2002).

\section{Hydroxybenzoic acids}<smiles>[R6]c1c(C)cc(C(=O)O)c([R])c1[R3]</smiles>

R4

$R 1=R 2=P 3=R 4=H$

$\mathrm{R} 1=\mathrm{R} 4=\mathrm{H}, \mathrm{R} 2=\mathrm{R} 3=\mathrm{OH}$

$\mathrm{R} 1=\mathrm{H}, \mathrm{R} 2=\mathrm{R} 3=\mathrm{R} 4=\mathrm{OH}$

$\mathrm{R} 1=\mathrm{OH}, \mathrm{R} 2=\mathrm{R} 3=\mathrm{R} 4=\mathrm{H}$

$\mathrm{H} 1: \mathrm{R} 4=\mathrm{OH}, \mathrm{R} 2=\mathrm{R} 3=\mathrm{H}$
Hydroxycinnamic acids<smiles>[R2]c1cc(/C=C/C(=O)O)cc([R])c1[R]</smiles>

\section{$\mathrm{R} 1=\mathrm{R} 2=\mathrm{OH}, \mathrm{R} 3$ \\ $\mathrm{R} 1=\mathrm{R} 3=\mathrm{H}, \mathrm{R} 2=\mathrm{OH}$ \\ $\mathrm{R} 1=\mathrm{OCH}_{3}, \mathrm{R} 2=\mathrm{OH}, \mathrm{R} 3=\mathrm{H}$ \\ $\mathrm{R} 1=\mathrm{R} 3=\mathrm{OCH}_{3}, \mathrm{R} 2=\mathrm{OH}$ \\ Caffeoyl quinic acid p-Coumaroyl quinic acid Feruloyl quinic acid Sinapoyl quinic acid}

\section{Hydroxybenzoic acids}<smiles>[R1]c1cc(C(=O)O)c([R])c([R2])c1[R3]</smiles>

$\mathrm{R} 1=\mathrm{R} 2=\mathrm{P} 3=\mathrm{R} 4=\mathrm{H}$ $\mathrm{R} 1=\mathrm{R} 4=\mathrm{H}, \mathrm{R} 2=\mathrm{R} 3=\mathrm{OH}$ $\mathrm{R} 1=\mathrm{H}, \mathrm{R} 2=\mathrm{R} 3=\mathrm{R} 4=\mathrm{OH}$ $\mathrm{R} 1=\mathrm{OH}, \mathrm{R} 2=\mathrm{R} 3=\mathrm{R} 4=\mathrm{H}$ $\mathrm{H} 1 \cdot \mathrm{R} 4=\mathrm{OH}, \mathrm{R} 2=\mathrm{R} 3=\mathrm{H}$

Benzoic acid (non phenolic) Protocatechic acid Gallic acid Salicylic acid Gentisıc acid

$\begin{array}{ll}\mathrm{R} 1=\mathrm{R} 2=\mathrm{R} 3=\mathrm{H} & \text { Cinnamic acid (non phenolic) } \\ \mathrm{R} 1=\mathrm{R} 3=\mathrm{H}, \mathrm{R} 2=\mathrm{OH} & \text {-Coumaric acid } \\ \mathrm{R} 1=\mathrm{R} 2=\mathrm{OH}, \mathrm{R} 3=\mathrm{H} & \text { Caffeic acid } \\ \mathrm{R} 1=\mathrm{OCH}, \mathrm{R} 2=\mathrm{OH}, \mathrm{R} 3=\mathrm{H} & \text { Ferulic acid } \\ \mathrm{R} 1=\mathrm{R} 3=\mathrm{OCH} \mathrm{H}_{3}, \mathrm{R} 2=\mathrm{OH} & \text { Sinapic acid }\end{array}$

Hydroxycinnamates (Chlorogenic acids)

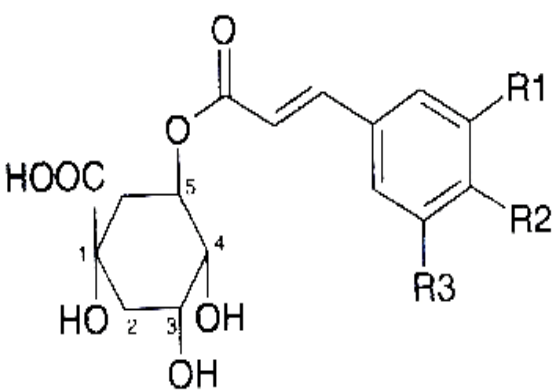

Hydroxycinnamic acids<smiles>[R2]c1cc(/C=C/C(=O)O)cc([R9])c1[R]</smiles>
$\mathrm{R} 1=\mathrm{R} 2=\mathrm{R} 3=\mathrm{H}$ Cinnamic acid (non phenolic) $\mathrm{R} 1=\mathrm{R} 3=\mathrm{H}, \mathrm{R} 2=\mathrm{OH}$ $\mathrm{R} 1=\mathrm{R} 2=\mathrm{OH}, \mathrm{R} 3=\mathrm{H}$ p-Coumaric acio $\mathrm{R} 1=\mathrm{OCH}_{3}, \mathrm{R2}=\mathrm{OH}, \mathrm{R3}=\mathrm{H} \quad$ Ferulic acid $\mathrm{R} 1=\mathrm{R} 3=\mathrm{OCH}_{3}, \mathrm{R} 2=\mathrm{OH} \quad$ Sinapic acid

Hydroxycinnamates (Chlorogenic acids)<smiles>[R3]c1cc(/C=C/C(=O)O[C@H]2C[C@@H](O)[C@@H](O)[C@@H](O)[C@@H]2O)cc([R])c1[R]</smiles>

Figure 1. Main phenolic acids and esters found in plant kingdom. Modified from Laguerre et al., (2007). 


\subsubsection{Flavonoids}

Flavonoids are a group of phenolic compounds with antioxidant activity that occur in several fruits, vegetables, and other plant foods (Lui, 2004). They are efficient antioxidants capable of scavenging radical species (Peroxyl radicals, hydroxyl radicals, $\mathrm{O}_{2}{ }^{-}$) forming a phenoxy radical (Lui, 2004). More than 4000 flavonoids have been identified and are classified into flavonols (quercetin, kaempferol, and myricetin) flavones (luteolin and apigenin) flavanols (catechin, epicatechin, epigallocatechin, epicatechin gallate, and epigallocatechin gallate), flavanones (naringenin), anthocyanidins and isoflavonoids (genistein) (Lui, 2004). The antioxidant properties of flavonoids have been investigated in various studies in vivo and in vitro. Flavonoids function as terminators of free radical chains and as chelators of redox-active metal ions that are capable of catalyzing lipid peroxidation (Schroeter et al., 2002). Flavonoids are ideal scavengers of peroxyl radicals due to their favourable reduction potentials relative to alkyl peroxyl radicals and thus in principle; they are effective inhibitors of lipid peroxidation (Schroeter et al., 2002). The presence of 3',4'-dihydroxystructure in ring B, presence of 2, 3- double bond in conjugation with the 4-oxo-group in ring $\mathrm{C}$ and the presence of a 5 - hydroxyl group in ring $\mathrm{A}$ with a 3 hydroxyl group and a 4-oxo function in the $\mathrm{C}$ - ring are all important contributors in the ability of flavonoids to scavenge free radical and chelate redox-active metal (Valko et al., 2006; Fraga, 2007). The nutritional benefit of flavonoids is generally linked with their healing potential (Polovka, 2003). A high flavonoid consumption has been associated with a decreased risk for cardiovascular disease (Arts et al., 2001; Mennen, et al., 2004) and lower rates of stomach, pancreatic, lung and possibly breast cancer (Damianaki et al., 2000).<smiles>c1ccc(C2CCCCC2)cc1</smiles>

Figure 2. The generic structure of flavonoids. Modified from (Liu, 2004)<smiles>O=c1cc(-c2ccccc2)oc2ccccc12</smiles>

Apigenin : $5=7=4^{\prime}=\mathrm{OH}$ Luteolin : $5=7=3^{\prime}=4^{\prime}=\mathrm{OH}$ Diosmetin : $5=7=3^{\prime}=\mathrm{OH}, 4^{\prime}=\mathrm{OCH}_{3}$ Isovitexin : $5=7=4^{\prime}=\mathrm{OH}, 6=$ Glucose

Flavanols<smiles>O[C@H]1Cc2ccccc2O[C@H]1c1ccccc1</smiles>

Catechin $\left(2^{*} \mathrm{R}, 3^{*} \mathrm{~S}\right): 5=7=3^{\prime}=4^{\prime}=\mathrm{OH}$ Epicatechin $\left(2^{*} \mathrm{R}, 3^{*} \mathrm{R}\right): 5=7=3^{\prime}=4^{\prime}=\mathrm{OH}$ Epigallocatechin $\left(2^{*} \mathrm{R}, 3^{*} \mathrm{R}\right): 5=7=3^{\prime}=4^{\prime}=5^{\prime}=\mathrm{OH}$ Epicatechin gallate $\left(2^{*} \mathrm{R}, 3^{*} R\right): \begin{aligned} 5=7=3^{\prime}=4^{\prime}=\mathrm{OH}, \\ 3-\text { gallic acid ester }\end{aligned}$<smiles>O=c1c(-c2ccccc2)coc2ccccc12</smiles>

Daidzein : $7=4^{\prime}=\mathrm{OH}$ Genistein : $5=7=4^{\prime}=\mathrm{OH}$<smiles>O=C1CC(c2ccccc2)Oc2ccccc21</smiles>

Naringenin : $5=7=4^{\prime}=\mathrm{OH}$

Hesperitin : $5=7=3^{\prime}=\mathrm{OH}, 4^{\prime}=\mathrm{OCH}_{3}$ Naringin : Naringenin-7-neohesperidoside Hesperidin : Hesperitin-7-nutinoside<smiles>O=c1c(O)c(-c2ccccc2)oc2ccccc12</smiles>

Kaempferol : $5=7=4^{\prime}=\mathrm{OH}$ Quercetin : $5=7=3^{\prime}=4^{\prime}=\mathrm{OH}$

Morin : $5=7=2^{\prime}=4^{\prime}=\mathrm{OH}$

Fisetin : $7=3^{\prime}=4^{\prime}=\mathrm{OH}$ Myricetin : $5=7=3^{\prime}=4^{\prime}=5^{\prime}=\mathrm{OH}$

Epigallocatechin gallate $\left(2^{*} \mathrm{R}, 3^{*} \mathrm{R}\right): 5=7=3^{\prime}=4^{\prime}=5^{\prime}=\mathrm{OH}$

Anthocyanidins

Pelargonidin : $5=7=4^{\prime}=\mathrm{OH}$

Cyanidin : $5=7=3^{\prime}=4^{\prime}=\mathrm{OH}$

Delphinidin : $5=7=3^{\prime}=4^{\prime}=5^{\prime}=\mathrm{OH}$

Malvidin : $5=7=4^{\prime}=\mathrm{OH}, 3^{\prime}=5^{\prime}=\mathrm{OCH}_{3}$

Anthocyanins

Cyanidln 3-glucoside

Cyanidin 3-galactoside

Cyanidin 3-rutinoside

Malvidin 3-glucoside

Figure 3. Chemical structures of common dietary flavonoids. Modified from (Laguerre et al., 2007) 


\section{Conclusion}

It has been identified that plants are rich sources of antioxidant Vitamin C, Vitamin E, flavonoids, and carotenoids. The potent antioxidant activity of plant extracts may in part be attributed to the presence of a plethora of different antioxidants with differing sites and mechanisms of action which may act alone or in concert with one another. Presence of dietary antioxidants, helps antioxidant defence system by preserving endogenous antioxidants from exhaustion as a result of oxidative stress. Therefore, supplementation with dietary antioxidants may be beneficial in reducing the risk of developing free radical mediated diseases such as cardiovascular disease, cancer, neurological disorders and diabetes.

\section{Authors' Contributions}

This work was carried out in collaboration between all authors. All authors read and approved the final manuscript.

\section{Conflict of Interests}

Authors have declared that no competing interests exist.

\section{References}

Adaramoye, O., Ogungbenro, B., Anyaegbu, O., Fafunso, M. (2008) Protective Effects of Extracts of Vernonia amygdalina, Hibiscus sabdariffa and Vitamin $\mathrm{C}$ against Radiation- induced Liver Damage in Rats. Journal of Radiation Research (Tokyo), 49 (2):123-31.

Ahuja, KD., Pittaway, JK., Ball, MJ. (2006) Effects of olive oil and tomato lycopene combination on serum lycopene, lipid profile, and lipid oxidation. Nutrition, 22(3):259-265.

Arts, IC., Jacobs, DR., Jr., Harnack, LJ., Gross, M., Folsom, AR. (2001) Dietary catechins in relation to coronary heart disease death among postmenopausal women. Epidemiology, 12: $668-675$.

Aviram, M., Kaplan, M., Rosenblat, M., Fuhrman, B. (2005) Dietary antioxidants and paraoxonases against LDL oxidation and atherosclerosis development. Handbook of experimental pharmacology, (170):263-300.

Bahadorani, S., Bahadorani, P., Phillips, JP., Hilliker, AJ. (2008) The effects of vitamin supplementation on Drosophila life span under normoxia and under oxidative stress. Journals of Gerontology Series A: Biological Sciences and Medical Science, 63(1):35-42.

Barondeau, DP., Kassmann, CJ., Bruns, CK., Tainer, JA., Getzoff, ED. (2004) Nickel superoxide dismutase structure and mechanism. Biochemistry, 43(25):8038-47.

Bose, KSC., Agrawal, BK. (2007) Effect of lycopene from cooked tomatoes on serum antioxidant enzymes, lipid peroxidation rate and lipid profile in coronary heart disease. Singapore Medical Journal, 48(5):415420.

Dalle-Donne, I., Rossi, R., Colombo, R., Giustarini, D., Milzani, A. (2006) Biomarkers of oxidative damage in human disease. Clinical Chemistry, 52:601-623.

Damianaki, A., Bakogeorgou, E., Kampa, M., Notas, G., Hatzoglou, A., Panagiotou, S., Gemetzi, C., Kouroumalis, E., Martin, PM., Castanas, E. (2000) Potent inhibitory action of red wine polyphenols on human breast cancer cells. Journal of cellular biochemistry, 78:429-441.

Dewanto, V., Wu, X., and Liu, RH. (2002) Processed Sweet Corn Has Higher Antioxidant Activity. Journal of Agricultural and Food Chemistry, $50: 4959-4964$

Evans, JI., Goldfine, ID., Maddux, BA., Grodsky, GM. (2002) Oxidative Stress and Stress-Activated Signaling Pathways: A Unifying Hypothesis of Type 2 Diabetes. Endocrine Reviews, 23 (5): 599-622.

Fraga, CG (2007) Plant Polyphenols, How to Translate their in vitro Antioxidant Actions to in vivo Conditions. IUBMB Life, $59(4-5): 308-315$.

Jenner, P. (2003) Oxidative stress in Parkinson's disease. Annals of neurology, 53: S26-38.

Kirsh VA, Hayes RB, Mayne ST, Chatterjee N, Subar AF, Dixon LB, Albanes D, Andriole GL, Urban DA, Peters U. (2006) Supplemental and dietary vitamin E, beta-carotene, and vitamin C intakes and prostate cancer risk. Journal of the National Cancer Institute, 98 (4) : 245-54.

Kovacic, P., Jacintho, JD. (2001) Mechanisms of carcinogenesis: Focus on oxidative stress and electron transfer. Current medicinal chemistry, $8: 773-796$

Laguerre, M., Lecomte, J., Villeneuve, P. (2007) Evaluation of the ability of antioxidants to counteract lipid oxidation: Existing methods, new trends and challenges. Progress in Lipid Research, 46 : 244-282.

Landis, GN., Tower, J. (2005) Superoxide dismutase evolution and life span regulation. Mechanisms of Ageing and Development, 126 (3) : 365-79.

Liu, RH. (2004) Potential synergy of phytochemicals in cancer prevention: mechanism of action. Journal of Nutrition, $134: 3479$ S-3485S.

Maritim, AC., Sanders, RA., Watkins, JB., (2003) Diabetes, oxidative stress, and antioxidants: Journal Biochemistry and Molecular Toxicology, 17, 24-38. 
Masella, R., Di Benedetto, R., Vari, R., Filesi, C., Giovannini, C. (2005) Novel mechanisms of natural antioxidant compounds in biological systems: Involvement of glutathione and glutathionerelated enzymes. Journal of Nutritional Biochemistry, $16: 577-586$.

Mates, JM., Perez-Gomez, C., De Castro, IN. (1999) Antioxidant enzymes and human diseases. Clinical Biochemistry, $32: 595-603$.

Mennen, LI., Sapinho, D., Bree, AD., Arnault, N., Bertrais, S., Galan, P., Hercberg, S. (2004) Consumption of Foods Rich in Flavonoids Is Related to a Decreased Cardiovascular Risk in Apparently Healthy French Women. Journal of Nutrition, $134: 923-926$.

Nogueira, JB. (2004) Antihypertensive pharmacogenetics. Revista portuguesa de cardiologia, 23 (12) : 16211630.

Orhan, H., Orhan, GH., Vriese, E., Vermeulen, NPE., Meerman, JNN. (2006) Application of lipid peroxidation and protein oxidation biomarkers for oxidative damage in mammalian cells. A comparison with two fluorescent probes. Toxicology in Vitro, 20:1005-1013.

Park, JE., Yang, JH., Yoon, SJ., Lee, JH., Yang, ES., Park, JW. (2003) Lipid peroxidation - mediated cytotoxicity and DNA damage in U937 cells. Biochimie, 84: 1198-1204.

Pastore, A., Federici, G., Bertini, E., Piemonte, F. (2003) Analysis of glutathione: Implication in redox and detoxification. Clinica chimica acta, $333: 19-39$.

Poli, G., Leonarduzzi, G., Biasi, F., Chiarpotto, E. (2004) Oxidative stress and cell signalling. Current medicinal chemistry, 11: 1163-1182.

Polovka, M., Brezova, V., Stasko, A. (2003) Antioxidant properties of tea investigated by EPR spectroscopy. Biophysical Chemistry, 106:39-56.

Rahman, K. (2001) Historical perspective on garlic and cardiovascular disease. Journal of Nutrition, 131(3s) : 977S-9S.

Ridnour, LA., Isenberg, JS., Espey, MG., Thomas, DD., Roberts, DD., Wink, DA. (2005) Nitric oxide regulates angiogenesis through a functional switch involving thrombospondin-1. Proceedings of the National Academy of Sciences of the United States of America, 102 : 13147-13152.

Sachindra, NM., Sato, E., Maeda, H., Hosokawa, M., Niwano, Y., Kohno, M., Miyashita K. (2007) Radical scavenging and singlet oxygen quenching activity of marine carotenoid fucoxanthin and its metabolites. Journal of Agricultural and Food Chemistry, 55 (21) : 8516-8522.

Sayre, LM., Smith, MA., Perry, G. (2001) Chemistry and biochemistry of oxidative stress in neurodegenerative disease. Current medicinal chemistry, 8: 721-738.

Schroeter, H., Boyd, C., Spencer, JPE., Williams, RJ., Cadenas, E., Rice-Evans, C. (2002) MAPK signaling in neurodegeneration: influences of flavonoids and of nitric oxide. Neurobiology, 861-880.

Shiva, SRCS., Subramanyam, MV., Vani, R., Asha, DS. (2007) In vitro models of oxidative stress in rat erythrocytes: effect of antioxidant supplements. Toxicology In Vitro. 21 (8) : 1355-1364.

Stocker, R., Keaney, JF. (2004) Role of oxidative modifications in atherosclerosis. Physiological reviews, 84 : $1381-1478$

Tariq, SA. (2007) Role of ascorbic acid in scavenging free radicals and lead toxicity from biosystems. Molecular Biotechnology, 37 (1) : 62-65.

Trevithick-Sutton, CC., Foote, CS., Collins, M., Trevithick, JR. (2006) The retinal carotenoids zeaxanthin and lutein scavenge superoxide and hydroxyl radicals: a chemiluminescence and ESR study. Molecular Vision, $12: 1127-35$

Turko, IV., Marcondes, S., Murad, F. (2001) Diabetes-associated nitration of tyrosine and inactivation of succinyl-CoA:3-oxoacid CoA-transferase. American Journal of Physiology, Heart and Circulatory Physiology, 281 (6) : H2289-94.

Turko, IV., Murad, F. (2002) Protein Nitration in Cardiovascular Diseases. Pharmacology Review, 54: 619-634.

Vaishampayan, U., Hussain, M., Banerjee, M., Seren, S., Sarkar,. FH, Fontana, J., Forman, JD., Cher, ML., Powell, I., Pontes, JE., Kucuk, O. (2007) Lycopene and soy isoflavones in the treatment of prostate cancer. Nutrition and cancer, 59 (1) : 1-7.

Valko, M., Leibfritz, D., Moncola, J., Mark T.D. Cronin, MTD., Mazura, M., Telser, J. (2007) Free radicals and antioxidants in normal physiological functions and human disease. The International Journal of Biochemistry and Cell Biology, 39 : 44-84.

Valko, M., Rhodes, CJ., Moncol, J., Izakovic, M., Mazur, M. (2006) Free radicals, metals and antioxidants in oxidative stress-induced cancer. Chemico-Biological Interactions, 6 (10) : 1-40. 